\title{
Stalk yield and nutrients accumulation of sugarcane varieties in three crop cycles
}

\section{Produção de colmos e acumulação de nutrientes por variedades de cana-de-açúcar em três ciclos de colheita}

\author{
Vinicius Santos Gomes da Silva ${ }^{*}$, Mauro Wagner de Oliveira², Vilma Marques Ferreira², \\ Terezinha Bezerra Albino Oliveira², Mayame de Brito Santana ${ }^{1}$ and Elaine Rocha Galvão ${ }^{3}$ \\ ${ }_{1}^{1}$ Departamento de Agronomia, Universidade Federal Rural de Pernambuco, Av. Dom Manoel de Medeiros, w/n, 52171-900, Recife, Pernambuco, Brasil \\ ${ }^{2}$ Centro de Ciências Agrárias, Universidade Federal de Alagoas, BR 104, Km 85, w/n, 57100-000. Rio Largo, Alagoas, Brasil \\ ${ }_{3}^{3}$ Departamento de Agronomia, Universidade do Estado da Bahia. Rua Edgar Chastinet, 48905-680, Cajueiro, Juazeiro - Bahia, Brasil \\ (*E-mail: vinicius.agro2008.1@gmail.com) \\ http://dx.doi.org/10.19084/RCA17051
}

Received/recebido: 2017.03.03

Received in revised form/recebido em versão revista: 2017.07.21

Accepted/aceite: 2017.08.01

\section{A B S T R A C T}

Sugarcane nutritional requirement knowledge has great importance for an adequate crop management, since allows the selection of efficient varieties in the use of nutrients, contributing to a better use of fertilizers and reduction of production costs. The aim of this study was to evaluate the stalks yield and the accumulation of nitrogen (N), phosphorus $(\mathrm{P})$, potassium $(\mathrm{K})$, calcium $(\mathrm{Ca})$, magnesium $(\mathrm{Mg})$, sulfur $(\mathrm{S})$, zinc $(\mathrm{Zn})$, copper $(\mathrm{Cu})$ and manganese $(\mathrm{Mn})$ of aerial biomass of four sugarcane varieties, RB867515, RB92579, SP813250 and VAT90212 during the plant-cane, first and second regrowth cycles. The experimental design was a randomized block with four treatments and five replicates. The cane was harvested due to maturity in the three crop cycles. The stalks yield and the nutrient accumulation of the aerial part of the varieties were evaluated. The stems yield presented were 126, 102 and $86 \mathrm{t} \mathrm{ha}^{-1}$ for plant-cane, first and second regrowth, respectively. Plant-cane macronutrients accumulation average presented the following decreasing order: $\mathrm{K}>\mathrm{N}>\mathrm{Ca}>\mathrm{Mg}>\mathrm{S}>\mathrm{P}$, for regrowth the observed sequence was $\mathrm{K}>\mathrm{N}>\mathrm{Ca}>\mathrm{S}>\mathrm{Mg}>\mathrm{P}$. The varieties presented high productive potential, and similar nutrients accumulation in the three cycles.

Keywords: nutritional requirement, nutrient content, uptake, nutritional efficiency, Saccharum spp.

\section{R E S U M O}

O conhecimento da exigência nutricional de variedades de cana-de-açúcar é de grande importância para um manuseamento adequado da cultura, pois possibilita a escolha de variedades eficientes no que se refere à utilização de nutrientes, contribuindo para uma melhor utilização de fertilizantes e redução dos custos de produção. O objetivo do trabalho foi avaliar a produtividade de colmos e a acumulação de azoto $(\mathrm{N})$, fósforo $(\mathrm{P})$, potássio $(\mathrm{K})$, cálcio $(\mathrm{Ca})$, magnésio $(\mathrm{Mg})$, enxofre $(\mathrm{S})$, ferro $(\mathrm{Fe})$, zinco $(\mathrm{Zn})$, cobre $(\mathrm{Cu})$ e manganês $(\mathrm{Mn})$ da biomassa da parte aérea de quatro variedades de cana-de-açúcar, RB867515, RB92579, SP813250 e VAT90212, nos ciclos de cana-planta, primeira e segunda rebrota. O delineamento experimental foi de blocos ao acaso com quatro tratamentos e cinco repetições. Na maturação e nos três ciclos de cultivo, a cana foi colhida e foram avaliadas a produtividade de colmos e a acumulação de nutrientes. A produtividade obtida foi de 126, 102 e $86 \mathrm{t} \mathrm{ha}^{-1}$ nos ciclos de cana-planta, primeira e segunda rebrota, respectivamente. Na cana-planta a acumulação média de macronutrientes foi a seguinte, por ordem decrescente: $\mathrm{K}>\mathrm{N}>\mathrm{Ca}>\mathrm{Mg}>\mathrm{S}>\mathrm{P}$, enquanto que nas rebrotas a sequência observada foi $\mathrm{K}>\mathrm{N}>\mathrm{Ca}>\mathrm{S}>\mathrm{Mg}>\mathrm{P}$. As variedades apresentaram alto potencial produtivo e foram semelhantes na acumulação de nutrientes nos três ciclos.

Palavras-chave: Exigência nutricional, teor de nutrientes, absorção, eficiência nutricional, Saccharum spp. 


\section{INTRODUCTION}

Sugarcane (Saccharum spp.) has a great socioeconomic importance for Brazil, currently the largest producer in the world. Most common uses are for sugar and alcohol production, human and animal feed (Oliveira et al., 2014). Brazil sugarcane area is about 9.0 million hectares, with average yield of $72 \mathrm{t} \mathrm{ha}^{-1}$ (Conab, 2016).

Currently, the Brazilian sugar and ethanol sector faces an agricultural (reduction in productivity) and industrial (factory closure) crisis. Thus, research is necessary to raise the yield and turn Brazilian cane more competitive. Some studies have recommended the use of liming, chemical or organic compost and green manure to increase sugarcane productivity (Oliveira et al., 2011; Calheiros et al., 2012). Another great practice for sugarcane cultivation success, when possible, is the choice of sugarcane varieties with greater nutritional and productive efficiency adapted to different soil and climatic environments.

Studies conducted in the Center-South of Brazil demonstrated that the varieties could differ in absorption and accumulation of nutrients (Franco et al., 2007; Tasso Júnior et al., 2007). However, there is a lack of nutrient accumulation research in the Northeast of Brazil that evaluates nutrient accumulation by cane varieties, and mostly available information refers to varieties that are no longer cultivated (Oliveira et al., 2010).

The differences in plant nutrient uptake, transport and accumulation are related to the morphological and physiological characteristics of the varieties associated with the absorption kinetics, including the nutrient influx rate, the Michaelis-Menten constant and the minimum concentration for liquid inflow activity occurrence (Marshner, 2012). A good variety is considered efficient when it has the capacity to absorb the nutrients and use them in the biomass production (Mendes, 2006).

The climatic factors, especially rainfall measure and distribution have great impact on nutrient availability, crop growth rate, nutritional efficiency, yield, and sugar quality. For this reason, it is recommended to carry out evaluations of sugarcane production for more than one year, aiming to contemplate both the climatic variations and crop age (Mendes, 2006; Silva et al., 2017a).

According to these considerations, the aim of this study was to evaluate, during plant-cane, first and second regrowth cycles, nutrient utilization efficiency of four varieties that represent more than $50 \%$ of sugarcane cultivation in Northeast Brazil.

\section{MATERIAL AND METHODS}

The study was conducted in an open field located in the Jequiá Farm, in the county of Anadia, Alagoas (Latitude $09^{\circ} 41^{\prime} 04^{\prime \prime} \mathrm{S}$ and Longitude $36^{\circ} 18^{\prime} 15^{\prime \prime} \mathrm{W}$ ). The experimental area belongs to Triunfo Mill, which is located in the county of Boca da Mata AL. The region has a rainy tropical climate, with dry summers, according to Koppen classification, with rainfall and temperatures annual averages of $1,500 \mathrm{~mm}$ (Figure 1) and $29^{\circ} \mathrm{C}$ (Silva et al., 2017b).

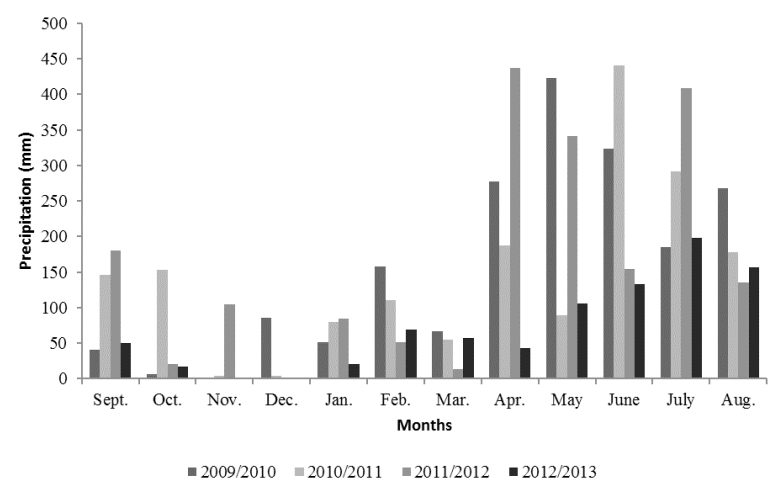

Figure 1 - Monthly precipitation during the studied period.

The soil was classified as a dystrophic Yellow Oxisol (Embrapa, 2013), with medium texture, and chemicals characterization were defined from soil samples collected in the layers $0.0-0.2 \mathrm{~m}$; $0.2-0.4 \mathrm{~m}$ (Table 1). Soil acidity was corrected using dolomitic limestone at a dose of $150 \mathrm{~kg} \mathrm{ha}^{-1}$, calculated considering the method to increase the saturation to $60 \%$ (Oliveira et al., 2007). After the limestone application, the soil was ploughed and harrowed, and then the grooves were opened for manual planting using sugarcane stalks with three buds per billets, and planting density between 15 and 18 buds per meter. 
Table 1 - Results of chemical analyses of soil samples for layers $0-20 \mathrm{~cm}$ and $20-40 \mathrm{~cm}$

\begin{tabular}{|c|c|c|c|c|c|c|c|c|c|}
\hline Layers & $\mathrm{pH}$ & $\mathbf{P}$ & $\mathbf{K}$ & $\mathrm{Ca}$ & $\mathrm{Mg}$ & Al & $\mathrm{H}+\mathrm{Al}$ & BS & CEC \\
\hline $\mathrm{cm}$ & \multicolumn{3}{|c|}{$-\mathrm{mg} \mathrm{dm}^{-3}$} & \multicolumn{6}{|c|}{ cmolc dm $^{-3}$} \\
\hline $00-20$ & 5.9 & 103.0 & 40 & 1.8 & 0.8 & 0.0 & 3.80 & 2.70 & 6.5 \\
\hline $20-40$ & 5.0 & 21.6 & 20 & 0.6 & 0.3 & 0.6 & 4.62 & 0.95 & 5.57 \\
\hline Layers & ECEC & V & $\mathbf{m}$ & SOM & $\mathrm{Zn}$ & $\mathrm{Fe}$ & Mn & $\mathrm{Cu}$ & B \\
\hline $\mathrm{cm}$ & cmolc dm $^{-3}$ & & $\%$ & & & & $\mathrm{mg} \mathrm{dm}^{-3}$ & & \\
\hline $00-20$ & 2.70 & 42 & 0 & 1.8 & 2.5 & 75.6 & 9.7 & 1.1 & 0.4 \\
\hline $20-40$ & 1.55 & 17 & 39 & 0.8 & 0.4 & 53.4 & 0.3 & 0.2 & 0.3 \\
\hline
\end{tabular}

pH in $\mathrm{H}_{2} \mathrm{O}$ (Ratio 1:2.5). P (phosphorus), $\mathrm{K}$ (potassium), Fe (iron), Zn (zinc), Mn (manganese) and Cu (copper): Mehlich extractor. Ca (calcium), Mg (magnesium) and Al (aluminium): KCI extractor. $\mathrm{H}+\mathrm{Al}$ (hydrogen + aluminium): Calcium acetate extractor. B (boron): Hot water extractor, $\mathrm{S}$ (sulfur): Monocalcium phosphate in acetic acid extractor. BS (base), CEC (cation exchange capacity), ECEC (effective cation exchange capacity), $\mathrm{V}$ (base saturation), $\mathrm{m}$ (aluminium saturation) and SOM (soil organic matter).

The experimental design was a randomized block with five replicates, consisting of four sugarcane varieties: SP813250, RB867515, RB92579 and VAT90212 grown in plots of six grooves of 10.0 meters in length, spaced from 1.0 meter, in a total of $60 \mathrm{~m}^{2}$ of area. The four central lines with six meters of length were considered for analysis, making up to $24 \mathrm{~m}^{2}$. These varieties were chosen based on their importance of being cultivated in up to $50 \%$ of the planted area of sugarcane in the Northeast of Brazil in the year before the implementation of the experiment.

Soil fertilization was based on Usina Triunfo recommendation according to the results of soil analysis (Table 1), applying 60, 100 and $150 \mathrm{~kg} \mathrm{ha}^{-1}$ of $\mathrm{N}, \mathrm{P}_{2} \mathrm{O}_{5}$ and $\mathrm{K}_{2} \mathrm{O}$ into the bottom of the groove. The cane was harvested after 14 months, and then the research was realized to the first and second regrowth, each one lasting 12 months. In these cycles all treatments received $500 \mathrm{~kg} \mathrm{ha}^{-1}$ of the formula 20-05-25 (NPK).

When cane reached maturity during the three analyzed cycles, the aerial part of 10 plants of each plot was randomly sampled. After sampling for nutrient accumulation estimative, the production of fresh biomass was determined by weighting the aerial part (stems, leaves and pointers) in an area of $2 \mathrm{~m}^{2}$ and then calculated the production of fresh biomass by hectare $\left(t \mathrm{ha}^{-1}\right)$.

The aerial part sampled was weighed and the total fresh matter mass was determined. Samples of fresh plant material were chopped, and then subsamples were collected. In the laboratory, the subsamples were dried in a forced air ventilation oven, at $65^{\circ} \mathrm{C}$, until constant weight. The material was weighed for dry subsample determination. The estimation of dry aerial biomass productivity $\left(\mathrm{t} \mathrm{ha}^{-1}\right)$ was determined by multiplying the percentage of dry vegetable matter by the production of fresh biomass per hectare. After obtaining the dry mass, the subsamples were passed in a Wiley type mill. The aerial biomass was analyzed to obtain nitrogen $(\mathrm{N})$, phosphorus $(\mathrm{P})$, potassium $(\mathrm{K})$, calcium $(\mathrm{Ca})$, magnesium $(\mathrm{Mg})$, sulfur $(\mathrm{S})$, zinc $(\mathrm{Zn})$, copper $(\mathrm{Cu})$, manganese (Mn) and boron (B) quantity according to the methods described by Malavolta et al. (1997). The $\mathrm{N}$ was extracted by sulfuric digestion and determined using the Kjeldahl method. Boron was extracted by dry digestion and determined by muffle method, the other nutrients were extracted by nitric - perchloric digestion. P was determined by the development of the blue color using reduction of the phospho-molybdic complex. $\mathrm{K}, \mathrm{Ca}, \mathrm{Mg}$, $\mathrm{Mn}, \mathrm{Zn}, \mathrm{Cu}$ and Fe were quantified by the atomic absorption spectrophotometry method and $\mathrm{S}$ by the barium sulfate turbidimetric method.

The data were analyzed using the Sisvar computer program (Ferreira, 2011), the variables were submitted to the analysis of variance by the Test $\mathrm{F}$ and, for those in which the F was significant, the means were compared with the Scott Knott test at a $5 \%$ probability. 


\section{RESULTS AND DISCUSSION}

Sugarcane varieties did not differ statistically for shoot yield, with 126, 102 and 86 tons per hectare for plant-cane, first and second regrowth, respectively (Figure 2). There was a $20 \%$ reduction in the stalks yield average, comparing the first regrowth to plant-cane, and less $16 \%$ from the first to the second regrowth. This productivity reduction between successive cycles has been reported in the literature (Mendes, 2006; Franco et al., 2011; Silva et al., 2017b). The decrease is attributed to the genetic characteristics of the varieties, the cultivars interactions and with the inserted environment (Silveira et al., 2012). Environmental factors related to plant growth such as luminosity, water availability (Oliveira et al., 2011) and mineral nutrients (Caione et al., 2013), as well as the inherent characteristics of varieties such as sprouting, age, and root activity may contribute to the decrease of productivity over the cycles (Manhães et al., 2015).

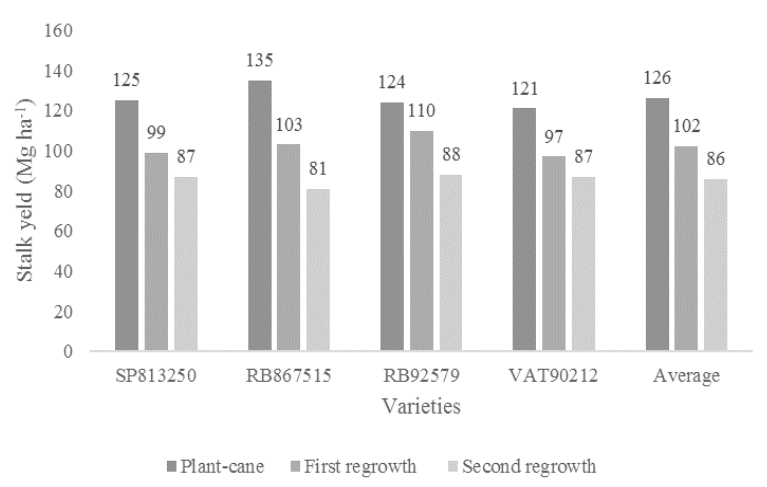

Figure 2 - Stalk yield for four sugarcane varieties in caneplant, first regrowth and second regrowth cycles.
The results obtained in the present study are similar to both studies obtained by other authors in the Northeast region and the Brazilian productivity average (Oliveira et al., 2011; Calheiros et al., 2012; Conab, 2016). The varieties used presented high productive potential as long as the accumulated biomass productivity can be considered from average to high for the State of Alagoas. Considering the phase of maximum sugarcane growth during short days with low luminosity and the non-coincidence of the maximum water availability, brings a negative impact to the photosynthetic rates, resulting in lower productivity in Alagoas, when compared to the Center-South (Oliveira et al., 2014).

No varietal effect was observed for nitrogen in the three cycles (Table 2). The average accumulation from plant-cane was $182 \mathrm{~kg} \mathrm{ha}^{-1}$, verified by Oliveira et al. (2011), which obtained $179 \mathrm{~kg} \mathrm{ha}^{-1}$ and $24 \%$ higher than what was reported by Mendes (2006) that found $137 \mathrm{~kg} \mathrm{ha}^{-1}$. Calheiros et al. (2012) in studies carried out in Alagoas State rainforest area verified for the plant-cane cycle that the varieties RB867515 and RB92579 had the same nutrient absorption capacity, and nitrogen accumulation in the shoot biomass for RB867515 and RB92579 was $220 \mathrm{~kg} \mathrm{ha}^{-1}$.

The high nitrogen extraction by sugarcane is due to its participation as constituent of many plant cells components, including amino acids, proteins and nucleic acids (Taiz and Zeiger, 2013). There are many studies in the literature that show the importance of $\mathrm{N}$ in the sugarcane crop (Franco et al., 2011). The nutrient is found only in $1 \%$ of the total dry mass of the plant, however its deficiency in the plant can cause a chlorophyll reduction, essential

Table 2 - Nitrogen $(N)$ and phosphorus accumulation in aerial biomass for four sugarcane varieties during plant-cane (PC), first regrowth (FR) and second regrowth (SR) cycles

\begin{tabular}{|c|c|c|c|c|c|c|c|c|}
\hline \multirow{2}{*}{ Varieties } & \multicolumn{4}{|c|}{ Nitrogen (kg ha-1) } & \multicolumn{4}{|c|}{ Phosphorus (kg ha-1) } \\
\hline & PC & FR & SR & Average & PC & FR & SR & Average \\
\hline VAT90212 & $176 \mathrm{a}$ & $125 \mathrm{a}$ & $109 \mathrm{a}$ & 135 & $29 \mathrm{a}$ & $20 \mathrm{a}$ & $18 \mathrm{a}$ & 22 \\
\hline SP813250 & $177 \mathrm{a}$ & $109 \mathrm{a}$ & $105 \mathrm{a}$ & 127 & $26 \mathrm{a}$ & $19 \mathrm{a}$ & $20 a$ & 22 \\
\hline RB867515 & $190 \mathrm{a}$ & $109 \mathrm{a}$ & $84 \mathrm{a}$ & 130 & $31 \mathrm{a}$ & $16 \mathrm{a}$ & $19 \mathrm{a}$ & 22 \\
\hline RB92579 & $183 \mathrm{a}$ & $127 \mathrm{a}$ & $95 \mathrm{a}$ & 135 & $24 \mathrm{a}$ & $16.8 \mathrm{a}$ & $18 \mathrm{a}$ & 19 \\
\hline Average & 182 & 118 & 98 & 132 & 27 & 18 & 19 & 21 \\
\hline C.V. (\%) & 14.8 & 16 & 13.6 & & 21.1 & 20.7 & 12.8 & \\
\hline
\end{tabular}

Means followed by the same letter do not differ statistically by Scott-Knott test at $5 \%$ probability. 
amino acids and the energy synthesis required to produce carbohydrates and carbon skeletons, reflecting directly on the development and crop yield (Taiz and Zeiger, 2013). Thus, the correct nitrogen fertilization application is fundamental to the success of sugarcane cultivation. Studies have shown that once the nitrogen fertilization is inadequate, it can result in the productivity reduction and crop longevity decrease, which causes anticipation of sugarcane plant renovation, increasing costs for producers (Franco et al., 2007).

The phosphorus accumulation was not influenced by the varieties in the three crop cycles (Table 2). In the plant-cane accumulation average in the shoot varieties biomass was $27 \mathrm{~kg} \mathrm{ha}^{-1}$; in the variety RB92579 was similar to the value observed in studies conducted by Calheiros et al. (2012), where they recorded a removal of $25 \mathrm{~kg} \mathrm{ha}^{-1}$ by RB867515 and was higher than the value observed by Oliveira et al. (2010) who obtained a removal of $19 \mathrm{~kg} \mathrm{ha}^{-1}$. Tasso Júnior et al. (2007) obtained an accumulation ranging from 17 to $25 \mathrm{~kg} \mathrm{ha}^{-1}$. In the first regrowth the accumulation average was higher than the value obtained by Benett et al. (2013), who found an average removal of $10 \mathrm{~kg} \mathrm{ha}^{-1}$ for RB867515. In the second regrowth the average accumulation was $19.15 \mathrm{~kg} \mathrm{ha}^{-1}$, this value was higher than that obtained by Gomes (2003) who found $5.07-15.31 \mathrm{~kg} \mathrm{ha}^{-1}$ for the second regrowth.

In general, the phosphorus content required by sugarcane is low, especially when compared to nitrogen and potassium. For sugarcane, phosphorus acts on both growth and production of sucrose, composing approximately $0.2 \%$ of the dry biomass of the plant. It is a structural component of macromolecules, such as nucleic acids and phospholipids, and also adenosine triphosphate (ATP), being a key element of several metabolic pathways and biochemical reactions, such as numerous steps in the Calvin cycle and glycolysis (Taiz and Zeiger, 2013). Thus, despite the low requirement, there is a need for frequent applications of $\mathrm{P}$ to provide and maintain high crop productivity (Teixeira et al., 2014).

For sugarcane, the phosphorus bioavailability in the plant can cause large changes in nitrogen uptake and metabolism (Magalhães, 1996). With an inadequate $\mathrm{P}$ supply there was a reduction in the nitrate uptake of the nutrient solution and the nitrate transport from the roots to the shoot also decreased, however, in plants with adequate $P$ supply the amino acids accumulation was high in leaves and roots (Alves et al., 1998). Considering the high P availability in the soil, presenting $103 \mathrm{mg}$ $\mathrm{dm}^{-3}$ of phosphorus, extracted with Mehlich-1 solution (Table 1) in the layer of 0 to $20 \mathrm{~cm}$, ensured that the element did not limit the plant growth.

Potassium was the nutrient accumulated in the highest amount during the three crop cycles, obtaining 219, 191 and $162 \mathrm{~kg} \mathrm{ha}^{-1}$ for plant-cane, first and second regrowth, respectively (Table 3). The highest extraction of this nutrient by sugarcane has been reported in the literature (Oliveira et al., 2011 e 2014). According to Oliveira et al. (2010) for a ton of stalk cane produced, a total of $1.72 \mathrm{~kg}$ of potassium are absorbed and removed with harvest. The great sugarcane potassium dependence is explained by the important role that this nutrient plays in regulating the osmotic potential of plant cells, and also activates many enzymes involved in respiration and photosynthesis processes (Taiz and Zeiger, 2013).

Table 3 - Potassium (K) and calcium (Ca) accumulation in aerial biomass for four varieties sugarcane during plant-cane (PC), first regrowth (FR) and second regrowth (SR) cycles

\begin{tabular}{ccccccccc}
\hline \multirow{2}{*}{ Varieties } & \multicolumn{4}{c}{ Potassium $\left(\mathbf{k g ~ h a}^{-\mathbf{1}}\right)$} & \multicolumn{3}{c}{ Calcium (kg ha-1) } \\
& PC & FR & SR & Average & PC & FR & SR & Average \\
\hline VAT90212 & $221 \mathrm{a}$ & $181 \mathrm{a}$ & $170 \mathrm{a}$ & 191 & $65 \mathrm{a}$ & $50 \mathrm{a}$ & $50 \mathrm{a}$ & 55 \\
SP813250 & $216 \mathrm{a}$ & $188 \mathrm{a}$ & $156 \mathrm{a}$ & 187 & $71 \mathrm{a}$ & $48 \mathrm{a}$ & $58 \mathrm{a}$ & 59 \\
RB867515 & $243 \mathrm{a}$ & $193 \mathrm{a}$ & $148 \mathrm{a}$ & 195 & $69 \mathrm{a}$ & $54 \mathrm{a}$ & $61 \mathrm{a}$ & 61 \\
RB92579 & $198 \mathrm{a}$ & $201 \mathrm{a}$ & $174 \mathrm{a}$ & 191 & $60 \mathrm{a}$ & $56 \mathrm{a}$ & $55 \mathrm{a}$ & 57 \\
\hline Average & 219 & 191 & 162 & 192 & 66 & 52 & 56 & 58 \\
C.V. (\%) & 10.8 & 18.4 & 13.4 & & 10.6 & 17.4 & 12.5 & \\
\hline
\end{tabular}

Means followed by the same letter do not differ statistically by Scott-Knott test at $5 \%$ probability. 
Table 4 - Magnesium (Mg) and sulphur (S) accumulation in aerial biomass for four sugarcane varieties during plant-cane (PC), first regrowth (FR) and second regrowth (SR) cycles

\begin{tabular}{ccccccccc}
\hline \multirow{2}{*}{ Varieties } & \multicolumn{4}{c}{ Magnesium $\left(\mathbf{k g ~ h a}^{-1}\right)$} & \multicolumn{4}{c}{ Sulfur (kg ha-1) } \\
& PC & FR & SR & Average & PC & FR & SR & Average \\
\hline VAT90212 & $57 \mathrm{a}$ & $38 \mathrm{a}$ & $40 \mathrm{a}$ & 45 & $51 \mathrm{a}$ & $37 \mathrm{a}$ & $40 \mathrm{a}$ & 42 \\
SP813250 & $59 \mathrm{a}$ & $45 \mathrm{a}$ & $40 \mathrm{a}$ & 48 & $64 \mathrm{a}$ & $46 \mathrm{a}$ & $46 \mathrm{a}$ & 52 \\
RB867515 & $66 \mathrm{a}$ & $46 \mathrm{a}$ & $36 \mathrm{a}$ & 49 & $64 \mathrm{a}$ & $40 \mathrm{a}$ & $37 \mathrm{a}$ & 47 \\
RB92579 & $57 \mathrm{a}$ & $40 \mathrm{a}$ & $45 \mathrm{a}$ & 47 & $58 \mathrm{a}$ & $48 \mathrm{a}$ & $46 \mathrm{a}$ & 51 \\
\hline Average & 60 & 42 & 41 & 47 & 59 & 43 & 43 & 48 \\
C.V. $(\%)$ & 22.8 & 19.2 & 16.8 & & 15.3 & 16.9 & 15.6 & \\
\hline
\end{tabular}

Means followed by the same letter do not differ statistically by Scott-Knott test at $5 \%$ probability.

In the plant-cane the average accumulation obtained was similar to that observed by Oliveira et al. (2014) in a study conducted in the Serra dos Aimorés - MG, that brought out an average accumulation of $221 \mathrm{~kg}^{\mathrm{ha}} \mathrm{h}^{-1}$ of $\mathrm{K}$ for RB867515 and RB92579. Oliveira et al. (2010) in a study conducted in a Yellow Argisol observed for RB867515 and RB92579 the same capacity of removing potassium extracting, $175 \mathrm{~kg} \mathrm{ha}^{-1}$ in average.

The potassium accumulation average during the first regrowth was $191 \mathrm{~kg} \mathrm{ha}^{-1}$, similar to Mendes (2006), who observed $198 \mathrm{~kg} \mathrm{ha}^{-1}$. In the second regrowth average was $162.17 \mathrm{~kg} \mathrm{ha}^{-1}$, Gomes (2003) obtained values ranging from 152 to $235 \mathrm{~kg} \mathrm{ha}^{-1}$.

For calcium accumulation, in the plant-cane cycle, the values obtained are lower than those obtained by Oliveira et al. (2010) and Mendes (2006), but higher than what was verified by Tasso Junior et al. (2007). The first regrowth presented average values higher than those obtained by Mendes (2006) and Prado et al. (2002) and lower than those observed by Oliveira et al. (2003). In the second regrowth, the average accumulation was $54.82 \mathrm{~kg} \mathrm{ha}^{-1}$ (Table 3).

Magnesium accumulation was $60.26 \mathrm{~kg} \mathrm{ha}^{-1}$, presenting lower values than those obtained by Oliveira et al. (2010) and higher than those of Mendes (2006). In the first regrowth the accumulation was lower to that obtained by Oliveira et al. (2003) and higher than those obtained by Prado et al. (2002) and Mendes et al. (2011), which were 21.9 and $31.7 \mathrm{~kg} \mathrm{ha}^{-1}$, respectively. For second regrowth the average accumulation was $41.03 \mathrm{~kg} \mathrm{ha}^{-1}$ (Table 4).
For sulfur, there was an accumulation in shoot biomass of $59.4 \mathrm{~kg} \mathrm{ha}^{-1}$, higher than the values reported by Tasso Júnior et al. (2007). In the first regrowth the mean accumulation was $48.6 \mathrm{~kg}^{\mathrm{h}} \mathrm{ha}^{-1}$ showing a higher accumulation compared to the results of Coleti et al. (2006) and Prado et al. (2002). For second regrowth the average was $43 \mathrm{~kg} \mathrm{ha}^{-1}$.

Plant-cane macronutrients accumulation average in the biomass of aerial part of the varieties presented the following descending order $\mathrm{K}>\mathrm{N}>$ $\mathrm{Ca}>\mathrm{Mg}>\mathrm{S}>\mathrm{P}$, but in the first and second regrowth the sequence observed was $\mathrm{K}>\mathrm{N}>\mathrm{Ca}>\mathrm{S}>\mathrm{Mg}>$ $\mathrm{P}$. The macronutrients, with the exception of phosphorus and calcium, showed a tendency to reduce accumulation in shoot biomass according to the descending order of plant-cane $>$ first regrowth $>$ second regrowth. Gomes (2003) obtained smaller accumulations of primary macronutrients in the first regrowth cycle, followed by second regrowth and plant-cane.

There was no varietal effect for the zinc and iron accumulation in the plant-cane and first regrowth cycles (Table 5). For second regrowth, a larger accumulation of these micronutrients was observed on RB867515 variety. Tasso Junior et al. (2011) evaluated the micronutrients extraction and exportation for five sugarcane varieties and obtained a zinc accumulation ranging from 245 to $535 \mathrm{~g} \mathrm{ha}^{-1}$ and iron ranging from 2,700 to $4,300 \mathrm{~g} \mathrm{ha}^{-1}$ in Red-Yellow Oxisol. Mendes et al. (2011) evaluating the micronutrients exportation by RB92579 in a Vertisol from the Submédio São Francisco region obtained an accumulation of $362 \mathrm{~g} \mathrm{ha}^{-1}$ approving the results of the present study. 
Table 5 - Zinc ( $\mathrm{Zn})$ and iron ( $\mathrm{Fe})$ accumulation in aerial biomass for four sugarcane varieties during plant-cane (PC), first regrowth (FR) and second regrowth (SR) cycles

\begin{tabular}{ccccccccc}
\hline \multirow{2}{*}{ Varieties } & \multicolumn{4}{c}{ Zinc $\left(\mathrm{g} \mathrm{ha}^{-1}\right)$} & \multicolumn{3}{c}{ Iron (g ha-1) } \\
& PC & FR & SR & Average & PC & FR & SR & Average \\
\hline VAT90212 & $313 \mathrm{a}$ & $225 \mathrm{a}$ & $314 \mathrm{a}$ & 284 & $4395 \mathrm{a}$ & $3634 \mathrm{a}$ & $2939 \mathrm{a}$ & 3656 \\
SP813250 & $335 \mathrm{a}$ & $204 \mathrm{a}$ & $346 \mathrm{a}$ & 328 & $4438 \mathrm{a}$ & $3500 \mathrm{a}$ & $3288 \mathrm{a}$ & 3742 \\
RB867515 & $387 \mathrm{a}$ & $242 \mathrm{a}$ & $457 \mathrm{~b}$ & 362 & $4138 \mathrm{a}$ & $3640 \mathrm{a}$ & $3589 \mathrm{~b}$ & 3789 \\
RB92579 & $345 \mathrm{a}$ & $268 \mathrm{a}$ & $342 \mathrm{a}$ & 318 & $3845 \mathrm{a}$ & $2961 \mathrm{a}$ & $2755 \mathrm{a}$ & 3187 \\
\hline Average & 345 & 235 & 377 & 319 & 4204 & 3434 & 3143 & 3593 \\
C.V. (\%) & 31.72 & 24.88 & 14.71 & & 19.91 & 55.24 & 12.11 & \\
\hline
\end{tabular}

Means followed by the same letter do not differ statistically by Scott-Knott test at $5 \%$ probability.

The copper and manganese contents available in the 0 to $20 \mathrm{~cm}$ depth layer extracted with Mehlich-1 solution were 0.6 and $4.7 \mathrm{mg} \mathrm{dm}^{-3}$, being lower than the critical levels defined by Marinho and Albuquerque (1981), conducted in Alagoas State, obtaining 0.80 and $6.0 \mathrm{mg} \mathrm{dm}^{-3}$ of copper and manganese, respectively. This fact can explain the low removal (Table 6) when compared to the compilation performed by Oliveira et al. (2007).

Foliar diagnosis studies may report if soil supply is adequate or if plants are deficient. In case of inadequately supplied corrective, efficient soil fertilization management is necessary. Copper and manganese deficiency can cause productivity potential damages, by reason of these elements participate in several oxidation-reduction reactions, especially in the photolysis of water, carbon and nitrogen metabolism (Marshner, 2012).

The average values of boron in shoot biomass of four sugarcane varieties in the plant-cane cycles, first and second regrowth, are shown in Table 7.
There was a varietal effect only in the second regrowth, with RB867515 providing greater accumulation. According to Oliveira et al. (2007), for a production of 150 tons of natural material, sugarcane extracts and accumulates 8.0, 3.0, 0.6, 0.4 and $0.3 \mathrm{~kg}$ of iron, manganese, zinc, copper and boron in shoot biomass, respectively. During the three cultivation cycles the varieties presented the following decreasing order of extraction: Iron $>$ Manganese $>$ Zinc $>$ Boron $>$ Copper.

Table 7 - Boron (B) accumulation in aerial biomass for four sugarcane varieties during plant-cane (PC), first regrowth (FR) and second regrowth (SR) cycles

\begin{tabular}{ccccc}
\hline \multirow{2}{*}{ Varieties } & PC & FR & SR & Average \\
\hline VAT90212 & $341 \mathrm{a}$ & $239 \mathrm{a}$ & $125 \mathrm{a}$ & 235 \\
SP813250 & $345 \mathrm{a}$ & $233 \mathrm{a}$ & $121 \mathrm{a}$ & 233 \\
RB867515 & $389 \mathrm{a}$ & $244 \mathrm{a}$ & $136 \mathrm{a}$ & 256 \\
RB92579 & $319 \mathrm{a}$ & $240 \mathrm{a}$ & $127 \mathrm{a}$ & 228 \\
\hline Average & 349 & 239 & 127 & 238 \\
C.V. $(\%)$ & 30,41 & 20,68 & 17,78 & \\
\hline
\end{tabular}

Means followed by the same letter do not differ statistically by Scott-Knott test at $5 \%$ probability.

Table 6 - Copper $(\mathrm{Cu})$ and manganese $(\mathrm{Mn})$ accumulation in aerial biomass for four sugarcane varieties during plant-cane (PC), first regrowth (FR) and second regrowth (SR) cycles

\begin{tabular}{|c|c|c|c|c|c|c|c|c|}
\hline \multirow{2}{*}{ Varieties } & \multicolumn{4}{|c|}{ Copper (g ha-1) } & \multicolumn{4}{|c|}{ Manganese (g ha-1) } \\
\hline & PC & FR & SR & Average & PC & FR & SR & Average \\
\hline VAT90212 & $75 \mathrm{a}$ & $47 \mathrm{a}$ & $48 \mathrm{a}$ & 66 & $639 a$ & $510 \mathrm{a}$ & $909 a$ & 686 \\
\hline SP813250 & 78 a & $40 \mathrm{a}$ & $60 \mathrm{a}$ & 59 & $634 \mathrm{a}$ & $608 \mathrm{a}$ & $1190 \mathrm{a}$ & 810 \\
\hline RB867515 & 73 a & 46 a & 56 a & 58 & $585 \mathrm{a}$ & $680 \mathrm{a}$ & $1035 \mathrm{a}$ & 766 \\
\hline RB92579 & $71 \mathrm{a}$ & $52 \mathrm{a}$ & $63 \mathrm{a}$ & 62 & $456 \mathrm{a}$ & $517 \mathrm{a}$ & $1052 \mathrm{a}$ & 675 \\
\hline Average & 74 & 46 & 57 & 59 & 578 & 579 & 1047 & 734 \\
\hline C.V. $(\%)$ & 18.85 & 17.40 & 29.54 & & 18.63 & 31.56 & 18.92 & \\
\hline
\end{tabular}




\section{CONCLUSIONS}

No difference was observed among the sugarcane varieties regarding stalk yield. In average the results were 126, 102 and $86 \mathrm{t} \mathrm{ha}^{-1}$, respectively for plant-cane, first and second regrowth.

For nutrients accumulation, no effect was also verified for the varieties. The average accumulation of $\mathrm{N}, \mathrm{P}, \mathrm{K}, \mathrm{Ca}, \mathrm{Mg}$ and $\mathrm{S}$ during the three harvesting cycles were, respectively, 396, 63, 576, 174, 141 and $144 \mathrm{~kg}$ per hectare.

\section{ACKNOWLEDGMENTS}

To the Triunfo Mill for the logistical support during this study. To Conselho Superior de Desenvolvimento Científico e Tecnológico (CNPq) for financial support and the fellowships conceded.

\section{REFERENCES}

Alves, V.M.C.; Magalhães, J.V.; Novais, R.F. Bahia Filho, A.F.C.; Oliveira, C.A. \& França, C.C.M. (1998) Localização de fósforo e de nitrogênio afetando os parâmetros cinéticos de absorção de nitrogênio em milho. Revista Brasileira de Fisiologia Vegetal, vol. 10, p. 197-201.

Benett, C.G.S.; Buzetti, S.; Silva, K.S., Teixeira Filho, M.C.M.; Costa, N.R.; Maeda, A.S. \& Andreotti, M. (2013) - Acúmulo de nutrientes no colmo de cana-de-açúcar em função de fontes e doses de manganês. Semina: Ciências Agrárias, vol. 34, n. 3, p. 1077-1088. http://dx.doi.org/10.5433/1679-0359.2013v34n3p1077

Caione, G.; Fernandes, F.M. \& Lange, A. (2013) - Efeito residual de fontes de fósforo nos atributos químicos do solo, nutrição e produtividade de biomassa da cana-de-açúcar. Revista Brasileira de Ciências Agrárias, vol. 8, n. 2, p. 189-196. http://dx.doi.org/10.5039/agraria.v8i2a2016

Calheiros, A.S.; Oliveira, M.W.; Ferreira, V.M.; Barbosa, G.V.S.; Santiago, A.D. \& Aristides E.V.S. (2012) Produção de biomassa, a partir de açúcar e proteína em função de variedades de cana-de-açúcar e adubação fosfatada. Semina: Ciências Agrárias, vol. 33, n. 2, p. 809-818. http://dx.doi.org/10.5433/1679-0359.2012v33n2p809

Coleti, J.T.; Casagrande, J.C.; Stupiello, J.J.; Ribeiro, L.D. \& Oliveira, G.R. (2006) - Remoção de macronutrientes pela cana-planta e cana-soca, em Argissolos, variedades RB83486 e SP81-3250. STAB - Açúcar, Álcool e Subprodutos, vol. 24, p. 32-36.

Conab (2016) - Acompanhamento da safra brasileira: cana-de-açúcar. Primeiro Levantamento, Companhia Nacional de Abastecimento. $66 \mathrm{p}$.

Embrapa. (2013) - Sistema brasileiro de classificação de solos. 3. a ed. Brasília, Empresa Brasileira De Pesquisa Agropecuária, Embrapa Solos, 353 p.

Ferreira, D.F. (2011) - Sisvar: a computer statistical analysis system. Ciência e Agrotecnologia. vol. 35, n. 6, p. 1039-1042. http://dx.doi.org/10.1590/S1413-70542011000600001

Franco, H.C.J.; Bolonga, I.R.; Faroni, C.E.; Vitti, A.C. \& Trivelin, P.C.O. (2007) - Acúmulo de macronutrientes em cana-de-açúcar em função da adubação nitrogenada e dos resíduos culturais incorporados ao solo no plantio. Bragantia, vol. 66, n. 4, p. 669-674. http://dx.doi.org/10.1590/S0006-87052007000400017

Franco, H.C.J.; Otto, R. Faroni, C.E.; Vitti, A.C.; Oliveira, E.C.A. \& Trivelin, P.C.O. (2011) - Nitrogen in sugarcane derived from fertilizer in Brazilian field conditions. Field Crop Research, vol. 121, n. 1, p. 29-41. http:// dx.doi.org/10.1016/j.fcr.2010.11.011

Gomes, J.F.F. (2003) - Produção de colmos e exportação de macronutrientes por primários cultivares de cana-de-açúcar (Saccharum spp.). Dissertação de Mestrado. Piracicaba, Escola Superior de Agricultura Luiz de Queiroz. 65 p.

Magalhães, J.V. (1996) - Absorção e translocação de nitrogênio por plantas de milho (Zea mays L.) submetidas a períodos crescentes de omissão de fósforo na solução nutritiva. Dissertação de Mestrado. Viçosa, Universidade Federal de Viçosa, 76 p.

Malavolta, E.; Vitti, G. C.; Oliveira, S.A. (1997) - Avaliação do estado nutricional das plantas: princípios e aplicações. 2. e ed. Piracicaba, Associação Brasileira para Pesquisa da Potassa e do Fosfato. 319 p. 
Manhães, C.M.C.; Garcia, R.F.; Francelino, F. M. A., Oliveira, H. F.; \& Coelho, F. C. (2015) - Fatores que afetam a brotação e o perfilhamento da cana-de-açúcar. Vértices, vol.17, n. 1, p. 163-181. http://dx.doi. org/10.5935/1809-2667.20150011

Marinho, M.L. \& Albuquerque, G.A.C. (1981) - Efeito do cobre e do zinco na produção de cana-de-açúcar em solos de tabuleiros de Alagoas. Brasil Açucareiro, vol. 98, p. 41-50.

Marschner, P. (2012) - Mineral Nutrition of higher plants. 3. a ed. San Diego, Elsevier, 651 p.

Mendes, A.M.S.; Moura, M.S.B; Silva, T.G.F.; Carmo, J.F.A.\& Brandão, E.O. (2011) - Acúmulo e exportação de micronutrientes pela cana de açúcar irrigada no Semiárido brasileiro. In: Congresso brasileiro de ciência do solo, 33. Uberlândia, Brasil, SBCS, p. 1-4.

Mendes, L.C. (2006) - Eficiência nutricional de cultivares de cana-de-açúcar. Dissertação de Mestrado. Viçosa, Universidade Federal de Viçosa. 46 p.

Oliveira, E.C.A.; Freire, F.J.; Oliveira, R.I.D.; Freire, M.B.G.S.; Simões Neto, D.E. \& Silva, S.A.M. (2010) Extração e exportação de nutrientes por variedades de cana-de-açúcar cultivadas sob irrigação plena. Revista Brasileira de Ciências do Solo, vol. 34, p. 1343-1352.

Oliveira, M.W.; Barbosa, M.H.P.; Damasceno, L.C. \& Mendes, C.M. (2003) - Matéria Seca e Nutrientes na Palhada de Dez Variedades de Cana-de-Açúcar STAB - Açúcar, Álcool e Subprodutos, vol. 21, p. 30-31.

Oliveira, M.W.; Freire, F.M.; Macêdo, G.A.R. \& Ferreira, J.J. (2007) - Nutrição mineral e adubação da cana-de-açúcar. Informe Agropecuário, vol. 28, n. 239, p. 30-43.

Oliveira, M.W.; Magrini, J.L.; Lyra, F.E.V.; Valduga, G.R.; Pereira, M.G.; Tenorio, C.J.M. \& Aristides, E.V.S. (2011) - Produção da RB867515 influenciada pela aplicação de substâncias húmicas, aminoácidos e extrato de algas marinhas. STAB - Açúcar, Álcool e Subprodutos, vol. 30, p. 30-33.

Oliveira, M.W.; Silva, V.S.G.; Reis, L.S.; Oliveira, D.C. \& Silva, J.C.T. (2014) - Produção e qualidade de três variedades de cana-de-açúcar cultivadas no nordeste de Minas Gerais. Revista Ciência Agrícola, vol. 12, n. 1, p. 17-20.

Prado, R.M.; Fernades, F.M. \& Natale, W. (2002) - Lime and slag evaluated by leaf analysis, macronutrient accumulation and export of sugarcane. Scientia Agricola, vol. 59, n. 1, p. 129-135. http://dx.doi.org/10.1590/ S0103-90162002000100019

Silva, V.S.G; Oliveira, M.W; Oliveira, T.B.A.; Mantovanelli, B.C.; Silva, A.C.; Soares, A.N.R. \& Clemente, P.R.A. (2017a) - Leaf area of sugarcane varieties and their correlation with biomass productivity in three cycles. African Journal of Agricultural Research, vol. 12, n. 7, p. 459-466. http://dx.doi.org/10.5897/AJAR2016.11817

Silva, V.S.G.; Oliveira, M. W.; Oliveira, D.C.; Oliveira, T.B.A.; Pereira, M.G. \& Nogueira, C.H.C. (2017b) Nutritional diagnosis of sugarcane varieties in a Yellow Oxisol during three agricultural seasons. African Journal of Agricultural Research, 12, n. 1, p. 50-57. http://dx.doi.org/10.5897/AJAR2016.11865

Silveira, L.C.I.; Kist, V.; Paula, T.O.M.; Barbosa, M.H.P.; Oliveira, R.A. de \& Daros, E. (2012) - Adaptabilidade e estabilidade fenotípica de genótipos de cana-de-açúcar no estado de Minas Gerais. Ciência Rural, vol. 42, n. 4, p. 587-593. http://dx.doi.org/10.1590/S0103-84782012000400002

Taiz, L. \& Zeiger, E. (2013) - Fisiologia vegetal 5.‥ ed. Porto Alegre, Artmed, 2013. 954 p.

Tasso Junior, L.C.; Marques, M.O.; Camilotti, F. \& Silva, T. (2007) - Extração e exportação de macronutrientes em cinco variedades de cana-de-açúcar cultivadas na região centro-norte do Estado de São Paulo. STAB - Açúcar, Álcool e Subprodutos, vol. 25, p. 38-42.

Tasso Junior, L.C.; Silva Neto, H. F., Silva, J.D.R., Marques, M.O. \& Camilotti, F. (2011) - Acúmulo de micronutrientes em colmos e palhada de cinco cultivares de cana-de-açúcar de ciclo precoce. Nucleus, vol. 8, n. 1, p. 375-384. http://dx.doi.org/10.3738/nucleus.v8i1.537

Teixeira, W.G.; Sousa, R.T.X. \& Korndörfer, G.H. (2014) - Resposta da cana-de-açúcar a doses de fósforo fornecidas por fertilizante organomineral. Bioscience Journal, vol. 30, n. 6, p. 1729-1736. 